Fall 1991

\title{
Justice Brennan's Gender Jurisprudence
}

Rebecca Korzec

University of Baltimore School of Law, rkorzec@ubalt.edu

Follow this and additional works at: http://scholarworks.law.ubalt.edu/all_fac

Part of the Civil Rights and Discrimination Commons, Judges Commons, Law and Gender Commons, and the Supreme Court of the United States Commons

\section{Recommended Citation}

Justice Brennan's Gender Jurisprudence, 25 Akron L. Rev. 315 (1991)

This Article is brought to you for free and open access by the Faculty Scholarship at ScholarWorks@University of Baltimore School of Law. It has been accepted for inclusion in All Faculty Scholarship by an authorized administrator of ScholarWorks@University of Baltimore School of Law. For more information, please contact snolan@ubalt.edu. 


\title{
JUSTICE BRENNAN'S GENDER JURISPRUDENCE
}

by

\author{
REBECCA KORZEC
}

INTRODUCTION

During his thirty-four year tenure on the Supreme Court, Justice William Joseph Brennan, Jr. demonstrated unparalleled sensitivity to the protection of individual rights. ${ }^{1}$ Justice Brennan's landmark opinions included Baker v. Carr, ${ }^{2}$ Goldberg v. Kelly, ${ }^{3}$ and New York Times Co. v. Sullivan. ${ }^{4}$ Before Brennan, Supreme Court jurisprudence exalted judicial passivity by employing techniques for avoiding constitutional issues, such as abstention, comity, exhaustion of remedies and the political question doctrine.

Against this background, Brennan became an active judicial voice in a series of innovative landmark cases, including decisions requiring federal officials to pay damages for violation of citizens' constitutional rights; ${ }^{6}$ authorizing federal courts to issue injunctions forbidding state court prosecutions under laws violating the First Amendment; ${ }^{7}$ and permitting congressional employees to sue members of Congress for discriminatory treatment. ${ }^{8}$

However, less attention has been focused on Justice Brennan's dramatic impact on the Supreme Court's gender jurisprudence. More than any other member of the Court, Justice Brennan recognized the complexity and pervasiveness of sex discrimination and its costs to society as a whole. Brennan's

- Professor, University of Baltimore School of Law.

' See, e.g., Totenberg, A Tribute to Justice William J. Brennan, Jr., 104 HaRV. L. REv. 33 (1990).

2369 U.S. 186 (1962) (apportionment decisions are not purely political and therefore justiciable).

3397 U.S. 254 (1970) (welfare as a property right protected by the due process clause).

4376 U.S. 254 (1964) (established actual malice standard in defamation actions involving public figures).

s See, e.g., Bickel, The Supreme Court 1960 Term - Foreword, The Passive Virtues, 75 HARv. L. Rev. 40 (1961).

${ }^{6}$ Bivens v. Six Unknown Named Agents of Federal Bureau of Narcotics, 403 U.S. 388 (1971).

'Dombrowski v. Pfister, 380 U.S. 479 (1965).

'Davis v. Passman, 442 U.S. 228 (1979).

9 Nothing in Justice Brennan's background foreshadowed his commitment to equality between the sexes. Justice Brennan was bom in 1906 in Newark, New Jersey, the second of eight children of Irish-Catholic immigrant parents. After attending parochial and public schools in Newark, Brennan graduated from the Wharton School of the University of Pennsylvania and from Harvard Law School in 1931. Brennan practiced labor law before becoming a New Jersey trial judge. In 1952, he was appointed to the Supreme Court of New Jersey. In 1956, President Eisenhower nominated Brennan to replace Associate Justice Sherman Minton. McQuade \& Kardos, Mr. Justice Brennan and His Legal Philosophy, 33 NOTRE DAME 
opinions recognized that sex differentiation is largely cultural in origin, rather than based on "real" gender differences. ${ }^{10}$ As a result, Justice Brennan created a truly independent gender jurisprudence, eventually emerging as the architect of the Supreme Court's contemporary test for evaluating claims of sex-based discrimination.

Understanding the significance of Brennan's contribution requires an appreciation of the Supreme Court's historical attitude towards sex-based discrimination. Before 1971, the Supreme Court uniformly upheld governmental classifications based on stereotypical and traditional role differences between men and women. Laws routinely classified individuals by gender, treating men and women as occupying separate spheres. Men occupied the sphere of wage-eamer, family head and societal actor. Women were assigned the roles of childbearer and rearer, and homemaker. These roles were thought to be mandated by nature and biology. Since men and women performed different roles, they could not stand as equals under the law. ${ }^{11}$

\section{Gender In Traditional Case Law}

Bradwell v. Illinois ${ }^{12}$ was the first case to raise a constitutional challenge to the different treatment of men and women. In that case, Myra Bradwell challenged the refusal of the State of Illinois to permit her to practice law solely because she was a woman. ${ }^{13}$ The United States Supreme Court held that the Illinois standard did not offend the Privileges and Immunities Clause of the Fourteenth Amendment. ${ }^{14}$ As described by Justice Bradley, "Man is, or should

L. REV. 321 (1958); cf., Vanderbilt, New Members of the Supreme Court of the United States, 43 A.B.A.J. 526 (1957):

For Mr. Justice Brennan the law is a living reality concerned with human beings, rather than a series of judicial declarations embalmed in judicial opinions. His enthusiasm is contagious and his ability to deal with judges and lawyers is outstanding. While he is keenly conscious of the fact that we live in a constantly changing world, he is equally aware of the fact that human nature changes very little. He is, therefore, instinctively inclined to preserve the essentials of all that is good in the past and to adapt them to the needs of the times.

${ }^{10}$ See, e.g., D. Rhode, Gender and Justice 63-80 (1990).

"See, e.g., Johnston, Sex and Property: The Common Law Tradition, 47 N.Y.U. L. REv. 1033, 1044-70 (1972). See Olsen, From False Paternalism to False Equality: Judicial Assaults on Feminist Community, Illinois 1869-1895, 84 Mich. L. Rev. 1518, 1523-29 (1986) (Bradwell's case as an example of false paternalism). See also In re Lockwood, 154 U.S. 116 (1894), in which the Supreme Court refused to issue a writ of mandamus requiring Virginia to admit to practice a woman who had already been admitted to the bars of the Supreme Court and the District of Columbia. The Virginia statute provided that any "person" admitted in any state or the District of Columbia could also be admitted in Virginia. "Person" was interpreted to mean "male."

1283 U.S. (16 Wall.) 130 (1872).

${ }^{13}$ Id. at 131.

${ }^{14}$ Id. at 139. 
be, woman's protector and defender. . . . The paramount destiny and mission of women are to fulfil the noble and benign offices of wife and mother. This is the law of the Creator."15

In Muller $v$. Oregon, ${ }^{16}$ the Court continued its deference to sex-based classifications. There, the statute at issue prohibited employing women in factories or laundries for more than ten hours per day. ${ }^{17}$ Three years earlier, in Lochner $v$. New York, ${ }^{18}$ the Court had invalidated a state "maximum hours" law for bakers, concluding that such a law was not a legitimate exercise of police power because it unnecessarily interfered with individual freedom of contract. ${ }^{19}$ Nevertheless, the hours limitation for women in Muller was found valid on familiar patemalistic grounds:

That woman's physical structure and the performance of maternal functions place her at a disadvantage in the struggle for subsistence is obvious. . . . Differentiated by these matters from the other sex, she is properly placed in a class by herself, and legislation designed for her protection may be sustained, even when like legislation is not necessary for men and could not be sustained. It is impossible to close one's eyes to the fact that she still looks to her brother and depends upon him. ${ }^{20}$

The Court continued to "protect" women from eaming a livelihood on the same basis as men in Goesart v. Cleary." There, the Court upheld a Michigan statute prohibiting the licensing of women as bartenders unless the woman was the wife or daughter of the male owner of a licensed bar or tavem. ${ }^{22}$ The Court did not even question the proposition that Michigan could prohibit all women from working as bartenders. Rather, the Court focused its attention on whether Michigan could create an exception for the daughters and wives of male owners. $^{23}$ In upholding the statute, the Court found a legitimate state interest in combatting moral and social problems, concluding that "the oversight assured through ownership of a bar by a barmaid's husband or father minimize hazards

\footnotetext{
15 Id. at 141. (Bradley, J., concurring). Justice Brennan employed this quote as an example of the law's "paternalistic attitude" in Frontiero v. Richardson, 411 U.S. 677 (1973).

${ }^{16} 208$ U.S. 412 (1908).

17 Jd. at 416.

18 198 U.S. 45 (15^5).

${ }^{19}$ Id. at 64-65.

${ }^{20} 208$ U.S. at 420-21.

${ }^{21} 335$ U.S. 464 (1948).

22 Id. at 467.

${ }^{23}$ Id. at 466 .
} 
that confront a barmaid without such protecting oversight." 24

Significantly, as late as 1961 the Warren Court approved sex-based distinctions which focused on woman as "the center of home and family life."25 In Hoyt $v$. Florida ${ }^{26}$ the Court unanimously upheld a state law which rendered males eligible for jury duty unless they requested an exemption, but automatically granted women an exemption unless they volunteered. ${ }^{27}$ In upholding the validity of this female exemption, the Court emphasized the centrality of woman's role as wife and mother "despite the enlightened emancipation of women from the restrictions and protections of bygone years, and their entry into many parts of community life formerly considered to be reserved to men. . . ."28 Moreover, administrative convenience permitted a broad exemption for all women rather than requiring a showing of actual family responsibility. ${ }^{29}$

Indeed, all sex-based discrimination cases decided before 1971 under the equal protection clause, were analyzed under the standard which the Supreme Court employs in reviewing purely economic classifications. Under this standard, the "rational relationship" test, the Court displays extreme deference to legislative judgments respecting sex roles and classifications. ${ }^{30}$

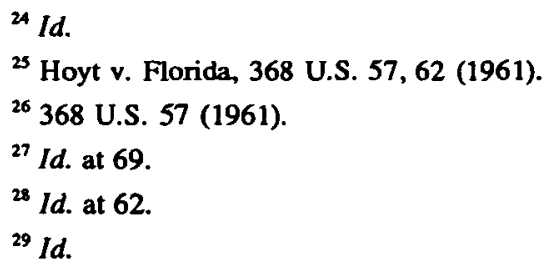

${ }^{30}$ See ELY, Democracy and Distrust (1980), drawing a connection between political powerlessness and gender classification. See also, L. KANOWIT, Women and the Law: The Unfinished Revolution (1969); Johnston \& Knapp, Sex Discrimination by Law, 46 N.Y.U. L. REV. 675, 756 (1971). The landmark work on equal protection analysis, Tussman \& TenBroek, The Equal Protection of the Laws, 37 CAL. L. REv. 341,344 (1949) remains the conceptual starting point. Tusmann and TenBroek have noted that

[here], then is a paradox: The equal protection of the laws is a "pledge of the protection of equal laws." But laws may classify. And "the very idea of classification is that of inequality." In tackling this paradox, the Court has neither abandoned the demand for equality nor denied the legislative right to classify. It has taken a middle course. It has resolved the contradictory demands of legislative specialization and constitutional generality by a doctrine of reasonable classification.

The essence of that doctrine can be stated with deceptive simplicity. The constitution does not require that things different in fact be treated in law as though they were the same. But it does require, in its concern for equality, that those who are similarly situated be similarly treated. The measure of the reasonableness of a classification is the degree of its success in treating similarly those similarly situated.

Goesart v. Gleary, supra, note 21, illustrates the degree of judicial deference accorded sex-based classifications before 1971. Justice Frankfurter noted:

"Since the line. . drawn is not without a basis in reason, we cannot give ear to the suggestion that the real impulse behind this legislation was an unchivalrous desire of male bartenders to try to monopolize the calling." 335 U.S. 464,467 (1948). 
Reed v. Reed ${ }^{31}$

In 1971, the use of this traditional standard of review ended abruptly in the Court's decision in Reed $v$. Reed..$^{32}$ In Reed, the Court unanimously invalidated an Idaho statutory scheme which established a method for the selection of administrators of intestate estates, requiring "males. . .be preferred to females" between persons "equally entitled" to administer the estate. ${ }^{33}$ This statutory preference for men was considered mandatory, without regard to individual qualifications to serve as administrator. ${ }^{34}$

The Reed Court ostensibly applied the traditional "rational relationship" test, inquiring whether the sex-based classification of the Idaho statute advanced a permissible statutory objective. ${ }^{35}$ Admittedly, the legislative scheme promoted the goal of administrative convenience, reducing the workload of probate courts by eliminating some contests for executor. ${ }^{36}$ The critical question, however, was whether the mandatory preference for men advanced this legitimate state objective in a manner which did not offend the Equal Protection Clause. ${ }^{37}$

The Court reasoned that giving ". . a mandatory preference to members of either sex over members of the other, merely to accomplish the elimination of hearings on the merits, is to make the very kind of arbitrary legislative choice forbidden by the Equal Protection Clause of the Fourteenth; and whatever may be said as to the positive values of avoiding intrafamily controversy, the choice in this context may not lawfully be mandated solely on the basis of sex." ${ }^{\text {38 }}$ (Emphasis added)

The Reed approach is a departure from the rational relationship test of Goesart or Hoyt. The administrative convenience for the Idaho probate courts in Reed was similar, if not greater, than that of the Florida scheme in Hoyt. Clearly, eliminating women from the class of potential claimants could reduce the probate caseload. However, achieving this legitimate administrative goal of reducing the

\footnotetext{
${ }^{31} 404$ U.S. 71 (1971).

${ }^{32}$ Id. The Court relied on F.S. Royster Guano Co. v. Vinginia, 253 U.S. 412,415 (1920). Reed, 404 U.S at 76. Royster held a "classification must be reasonable, not arbitrary, and must rest upon some ground of difference having a fair and substantial relation to the object of the legislation, so that all persons similarly circumstanced shall be treated alike." Royster, 253 U.S. at 415.
}

${ }^{33}$ Reed, 404 U.S. at 76.

34. Id. at 77.

${ }^{35}$ Id. at 76.

${ }^{36} \mathrm{Id}$.

37 Id.

${ }^{38}$ Id. at $76-77$. 
judicial caseload could not be accomplished by such impermissible, arbitrary means. The Idaho statute would not result in the selection of the most competent executors unless it were based on the assumption that women are inherently less capable than men in administering estates. The Court concluded that such an assumption rendered the Idaho scheme arbitrary. For the first time, the Court demonstrated "some special sensitivity to sex as a classifying factor. . . ." It is against this historical background that Justice Brennan's significant contributions to the law of sex-based discrimination should be evaluated.

\section{BRENNAN'S GENDER DECISIONS}

Frontiero v. Richardson ${ }^{40}$ was first in the series of sex-based discrimination opinions by Justice Brennan. Frontiero involved a challenge to a federal statute which provided that spouses of male members of the armed services were automatically considered "dependents" for purposes of obtaining increased allowances and benefits, while spouses of female members were required to demonstrate dependency on their wives for over half of their support. ${ }^{41}$ With only one dissenter, the Court concluded that this sex-based difference violated the Due Process clause of the Fifth Amendment. ${ }^{42}$

As author of the plurality opinion, Justice Brennan asserted that sex should be deemed a suspect classification requiring the highest standard of judicial review. ${ }^{43}$ In examining the history and effect of discrimination against women, Justice Brennan found that "classifications based upon sex, like classifications based upon race, alienage, and national origin are inherently suspect, and must therefore be subjected to close judicial scrutiny. ${ }^{\text {44 }}$ In effect, Brennan created an independent gender discrimination jurisprudence.

Next, Justice Brennan addressed the rationale of the Frontiero statutory scheme. The government offered administrative convenience as the sole justification for its discriminatory scheme: Congress might find it efficient to create a conclusive presumption of female dependence, ${ }^{45}$ while requiring actual proof of male dependence. However, when pressed, the government failed to prove actual economic savings. ${ }^{46}$ Ultimately, Justice Brennan concluded that the

"Gunther, The Supreme Court 1971 Term, Foreword: In Search of Evolving Doctrine on a Changing Court: A Model for a Newer Equal Protection, 86 HARv. L. REv. 1, 34 (1972).

${ }^{40} 411$ U.S. 677 (1971).

${ }^{41}$ Id. at 679.

${ }^{42} I d$. at 691 .

${ }^{43} I d$. at 688.

${ }^{44}$ Id. at 687-88.

${ }^{45}$ Id. at 689 .

${ }^{46}$ Id. at 686 . 
goal of administrative convenience could not justify sex-based classifications, which promoted "romantic paternalism" acting to "put women not on a pedestal, but in a cage."

The significance of Justice Brennan's ultimately unsuccessful attempt to have sex declared a suspect classification cannot be overestimated. The Supreme Court treats governmental classifications based on race and national origin as suspect, subjecting them to strict scrutiny. For the most part, strict scrutiny invalidates classifications while rational relationship almost always upholds the governmental scheme. Professor Gunther has noted that, as a practical matter, this strict standard of judicial review is "fatal in fact" to a classification. ${ }^{48}$

Having failed to attract the necessary votes to declare sex a suspect classification, Justice Brennan modified his position in Craig v. Boren. ${ }^{49}$ The Craig Court invalidated Oklahoma statutes prohibiting the sale of $3.2 \%$ beer to males under 21 and females under $18 .^{50}$ The state argued that statistical surveys demonstrated a high correlation between sex and alcohol-related driving offenses in that $2 \%$ of males but only $18 \%$ of females aged $18-20$ had such driving

${ }^{47}$ Id. at 684 . Justice Brennan specifically asserted that what differentiates sex from such nonsuspect categories as intelligence or physical disability, and aligns it with the recognized suspect criteria, is that the sex characteristic frequently bears no relation to ability to perform or contribute to society. As a result, statutory distinctions between the sexes often have the effect of invidiously relegating the entire class of females to inferior legal status without regard to the actual capabilities of its individual members. Id. at 686.

${ }^{48}$ Gunther, supra, note 39 , at 8.

In his 1975 opinion for the Court in Weinberger v. Wiesenfeld, 420 U.S. 636 (1975), Brennan hinted that he would adopt a different approach to accommodate the reluctance of the other justices to treat sex-based classifications as inherently suspect. Wiesenfeld involved a provision of the Social Security Act which provided survivors' benefits directly to widows having minor children in their care, while widowers with minor children received benefits only for their children. The Court invalidated the statute under Frontiero. Id. at 642-43. Justice Brennan reasoned that both provisions assumed that the earnings of male workers, but not those of females, were vital to the family unit. Id. at 643 . Brennan viewed this legislative scheme as "denigrat[ing] . . . the efforts of women who do work and whose eamings contribute significantly to their families' support. Id. at 645 . To gain a consensus, Justice Brennan refrained from grounding his analysis on sex as a suspect classification, emphasizing Reed as well as Frontiero. Id. at 642-53. See also Califano v. Goldfarb, 430 U.S. 199 (1977), in which Justice Brennan, writing for a plurality of the Court, struck down a Social Security Act provision which granted a widow survivors' benefits based on her deceased husband's earnings, while permitting a widower benefits only if he had received at least one-half of his support from his deceased wife. Significantly, Justice Brennan viewed this scherne as discriminatory against covered wage-earning women who received less protection for their spouses than enjoyed by similarly situated men. Id. at 206-07. (". . . the presumption of wives' dependency . . . is . . . based simply on 'archaic and overbroad' generalizations. ...) Id. at 217.

49429 U.S. 190 (1976). Nevertheless, Justice Brennan held firm to the sex as suspect classification theory, requiring the strictest scrutiny, regardless of whether men or women were disadvantaged by the classifications. This analysis applied as well when the legislation was considered benign or compensatory in nature. See, e.g., Kahn v. Shevin, 416 U.S. 351, 357 (1974) (Brennan, J.).

so 429 U.S. at 210. 
arrests. $^{51}$ Unpersuaded by the statistical evidence, Justice Brennan concluded that Oklahoma had failed to prove that "sex represents a legitimate, accurate proxy for the regulation of drinking and driving." 52 Consequently, the Oklahoma legislative scheme failed to satisfy an "intermediate scrutiny" test requiring that sex-based classifications "must be substantially related to achievement of those objectives. ${ }^{53}$

Justice Brennan expressed particular concern that "[t]he very social stereotypes that find reflection in age differential laws. . . are likely substantially to distort the accuracy of these comparative statistics. Hence 'reckless' young men who drink and drive are transformed into arrest statistics, whereas their female counterparts are chivalrously escorted home." while bending to the pragmatic need to abandon the Frontiero sex-as-suspectclassification standard, reflected Justice Brennan's conviction that sex differentiation is largely culturally created. ${ }^{55}$ Under the intermediate or "mid-level" scrutiny developed by Brennan in Craig $v$. Boren, the sex-based statutory classification must be substantially related to achieving an important governmental goal. ${ }^{56}$ Brennan created the following framework for analyzing equal protection challenges to statutes containing sex-based classifications: The classification can withstand constitutional challenge only if it is substantially related to the achievement of an important governmental objective. ${ }^{57}$ Justice Brennan would apply this standard for classifications which discriminate against men as well as women. In meeting its burden, the government must demonstrate that a genderneutral statute would be less effective in achieving the important governmental goal. $^{58}$

\footnotetext{
${ }^{31}$ Id. at 201.

32 Id. at 204.
}

${ }^{33}$ Id. at 197. See also, Rostker v. Goldberg, 453 U.S. 57 (1981); Mississippi University For Women v. Hogan. 458 U.S. 718 (1982) (Equal protection challenge by qualified male for admission to nursing school denied solely because of gender).

${ }^{54}$ Craig, 429 U.S. at 202 n.14. Prior to Craig, the Court had employed "... a spectrum of standards in reviewing discrimination violative of the Equal Protection Clause." San Antonio Indep. School Dist. v. Rodriguez, 411 U.S. 1, 98-99 (Marshall, J., dissenting).

ss See Freedman, Sex Equality, Sex Differences, and the Supreme Court, 92 YALE LJ. 913 (1983). Professor Freedman contrasts the approach of Justices Rehnquist and Stewart with that of Brennan and Marshall to sex-based discrimination. In Freedman's view, Rehniquist and Stewart focus on whether in a particular case there are "real" (biological) differences between men and women. On the other hand, Justice Brennan views sex discrimination as more pervasive and morally problematic. See also Law, Rethinking Sex and the Constitution, 132 U. PA. L. REv. 955 (1984); Wildman, The Legitimation of Sex Discrimination: A Critical Response to Supreme Court Jurisprudence, 63 OR. L REV. 265 (1984); Comment, The "Substantial Relation" Question in Gender Discrimination Cases, 52 U. CHI. L. REv. 149 (1985).

s6 429 U.S. at 197.

37 Id.

58 This approach rejects the use and perpetuation of traditional sex roles as a legitimate governmental purpose, creating a presumption against the validity of sex-based classifications. Justice Brennan would then employ a means ends analysis to determine the actual purpose of the classification and whether that classification is substantially related to the legislative goal. In completing this analysis, Brennan would 
Justice Brennan applied the Craig intermediate standard of review in Orr v. Orr. ${ }^{59}$ In Orr, the Court invalidated an Alabama law which imposed the duty to pay alimony on men only. ${ }^{60}$ Brennan particularly objected to the Alabama legislation's assigning a dependent role to wives within the family, since such sex-role allocation no longer reflected the reality of women's participation in the contemporary work force. ${ }^{61}$

Justice Brennan was less likely than other members of the Court to accept classifications based on the distinctive reproductive characteristics of the sexes. Brennan's dissent in Michael M. v. Superior Court of Sonoma County ${ }^{62}$ County is a convincing example. Michael $\mathbf{M}$. was prosecuted under California's statutory rape law, which penalizes men for engaging in sexual intercourse with females under eighteen. ${ }^{63}$ Writing for the plurality, Justice Rehnquist exhibited great deference towards the state's justification for the statutory rape law: the prevention of teenage pregnancy. Rehnquist concluded that, since only females can become pregnant, men and women are not similarly situated "with respect to the problems and the risks of sexual intercourse."64 Since the threat of pregnancy sufficiently deterred young females, the legislature could create a deterrent for young men by imposing criminal penalties. ${ }^{65}$

Justice Brennan, in dissent, found that Califomia had presented no evidence to prove that the threat of pregnancy deterred young females. ${ }^{66}$ Significantly, Brennan concluded that California's statutory rape law resulted from "outmoded sexual stereotypes" which view males as sexual aggressors. ${ }^{67}$

Justice Brennan consistently views "protective" or "benign" sex-based classifications as discriminatory. In Kahn $v$. Shevin, ${ }^{68}$ the Court upheld a Florida law granting widows a $\$ 500$ property tax exemption. ${ }^{69}$ Although the statutory

ask whether sex is an accurate proxy for the characteristics related to the goal and whether a sex-neutral rule could be equally effective. Freedman, supra note 55 at 926 . See also Ginsburg, Sex Equality and the Constitution, 52 TuL. L. REV. 451, 468-69 (1978).

59440 U.S. 268,279 (1979).

${ }^{60} I d$. at 283.

${ }^{61} I d$.

62450 U.S. 464 (1981).

${ }^{63} \mathrm{Id}$. at 466.

64 Id. at 471.

${ }^{65} I d$. at 464.

${ }^{66}$ Id. at 492.

${ }^{67}$ Id. at 496.

416 U.S. 351 (1974). See Ginsburg, Some Thoughts on Benign Classification in the Context of Sex. 10 CONN. L. REV. 813 (1978).

${ }^{69} 416$ U.S. at 356. 
exemption had been created in 1855 on the assumption that all widows had been financially dependent on their husbands, the majority accepted Florida's argument that the law was intended to alleviate past economic discrimination against women. $^{70}$ Justice Brennan dissented, finding no compelling govermmental interest in the Florida legislative scheme. ${ }^{71}$ Justice Brennan felt that the difficulty with Kahn $v$. Shevin was that it relegated widows to a permanent, separate status, regardless of wealth or business experience. At the same time, it denied the state's "benevolence" to widowers who may be needy or unsophisticated. $^{72}$ As such, the Florida statutory scheme perpetuates historical sex-role stereotypes which ultimately disadvantage both men and women. ${ }^{73}$

Justice Brennan's consistent attempt to invalidate most sex-based classifications is grounded in his view that such discrimination is a deeply-rooted, historical phenomenon. For example, in Frontiero Brennan confronted the "long and unfortunate history of sex discrimination"74 which remains "pervasive" in society as "discrimination against women in our educational institutions, in the job market, and perhaps most conspicuously, in the political arena." 75 The result of this continuing discrimination is that all sex-based laws, even those which ostensibly benefit women, "carry the inherent risk of reinforcing stereotypes about the proper place of women and their need for special protection." ${ }^{176}$ The consequence of such "protection" is that the laws are predicated on inaccurate and inequitable assumptions about the roles played by men and women.

Justice Brennan dissented again in Schlesinger $v$. Ballard.7 There, the Court faced a challenge to a Federal statute subjecting a male navy officer who twice failed to be selected for promotion to mandatory discharge regardless of the length of time he had been in active service. ${ }^{78}$ Under a different statute, a female officer was subject to mandatory discharge only after thirteen years of active service without promotion. ${ }^{79}$ In upholding the regulation, the Cour found that, because female officers were not assigned to combat duty and thus had less opportunity for advancement than male officers, the two groups were not similarly situated. ${ }^{80}$ As a result, the classification was seen as compensatory rather than

\footnotetext{
${ }^{70}$ Id. at 357.

${ }^{71}$ Id. at 357-58 (Brennan, J., dissenting).

${ }^{2}$ Id.

${ }^{73}$ Id. at 360.

${ }^{74} 411$ U.S. 677,684 (1971).

${ }^{75}$ Id. at 686.

${ }^{76} \mathrm{Id}$.

7419 U.S. 498 (1975).

${ }^{78}$ Id. at 499 n.1.

${ }^{79}$ Id. at 499-500 and n.2.

${ }^{80}$ Id. at 508 .
} 
discriminatory. ${ }^{81}$ The majority observed that the "longer period of tenure for women officers would, therefore, be consistent with the goal to provide women officers with 'fair and equitable career advancement programs." 82 Justice Brennan argued that because gender classification was involved, the legislation must be examined under the strict scrutiny standard. ${ }^{83} \mathrm{He}$ also noted that the legislative history failed to demonstrate a compensatory purpose with regard to female officers. ${ }^{84}$ On the contrary, in Brennan's view "the legislative history [was] replete with indications of a decision not to give women any special advantage." 85

Significantly, in Geduldig v. Aiello, ${ }^{86}$ Brennan dissented from the Court's application of the mere rational basis standard to the statutory exclusion of pregnancy benefits from Califomia's disability insurance program. ${ }^{87}$ Incredibly, the Geduldig majority insisted that the exclusion of pregnancy did not involve a gender-based classification, but rather a distinction between pregnant and monpregnant persons. ${ }^{88}$ Dissenting, Justice Brennan argued that:

By singling out for less favorable treatment a gender-linked disability peculiar to women, the State has created a double standard for disability compensation. ... Such dissimilar treatment of men and women, on the basis of physical characteristics inextricably linked to one sex, inevitably constitutes sex discrimination. ${ }^{89}$

Justice Brennan again assumed the role of passionate dissenter ${ }^{90}$ in Personnel Administrator v. Feeney. ${ }^{91}$ The statute in question was concededly gender-neutrai on its face ${ }^{92}$ in that it gave preference to veterans over nonveterans in employment. The majority concluded that the statutory scheme did

${ }^{21}$ Id.

${ }^{82}$ Id. (quoting H.R. REP. No. 216, 90th Cong. (1967)).

${ }^{83}$ Id. at 511 (Brennan, J., dissenting).

${ }^{04}$ Id. at 514 (Brennan, J., dissenting).

is Id. at 516 (Brennan, J., dissenting).

${ }^{86} 417$ U.S. 484 (1974).

${ }^{07}$ Id. at 498 (Brennan, J., dissenting).

${ }^{80}$ Id. at 496 n.20.

${ }^{99}$ Id. at 501 (Brennen, J., dissenting).

${ }^{90}$ The "intermediate tier" standard of review created by Justice Brennan in Craig v. Boren continues to be employed in various factual contexts. See, e.g., City of Cleburne v. Cleburne Living Center, 473 U.S. \$32 (1985). However, in gender-based classification cases the Court's decisions often have placed Brennan in the posture of dissenter.

91442 U.S. 256 (1979).

IId. at 274 . 
not constitute invidious discrimination ${ }^{93}$ even though $98 \%$ of veterans were male. ${ }^{94}$ On the other hand, Justice Brennan joined Justice Marshall in recognizing that the statute, while facially gender-neutral, in fact, discriminated against women by "render[ing] desirable state civil service employment an almost exclusively male prerogative."

In Roberts $v$. United States Jaycees, ${ }^{96}$ Justice Brennan enjoyed a now-rare position writing for the Court rather than in dissent. ${ }^{97}$ Brennan faced a conflict between First Amendment individual liberties and anti-discrimination state laws. At issue was the membership scheme of the national Jaycees which limited regular membership to men. ${ }^{98}$ Two Minnesota chapters began accepting women as regular members, arguing that the Minnesota Human Rights Act mandated this action. The national organization alleged its First Amendment rights of speech and association had been abridged. ${ }^{99}$ Although Justice Brennan conceded that application of the Minnesota Human Rights Act would cause "incidental abridgment"100 of protected speech, such de minimis restriction was necessary to achieve the state's legitimate purpose in attacking invidious gender discrimination. ${ }^{101}$

\section{Privacy and Personal Autonomy}

Justice Brennan's views on privacy and personal autonomy were grounded in his belief that the Constitution is subject to "contemporary ratification."102 By this, Brennan meant that the Court must promote human dignity and personal autonomy as measured by changing societal needs and values, rather than by the

${ }^{93}$ Id. at $280-81$.

${ }^{94}$ Id. at $270-71$.

${ }^{95}$ Id. at 283. (Marshall, J., dissenting). See also, Rostker v. Goldberg, 453 U.S. 57 (1981), holding that the Selective Service Act, which required registration of males only did not violate the Fifth Amendment. Id. at 83. Justice Brennan again dissented.

${ }^{96} 468$ U.S. 609 (1984).

${ }^{97}$ Id. at 612 .

${ }^{98} \mathrm{Id}$.

${ }^{99} \mathrm{Id}$. at 614 .

${ }^{100}$ Id. at 628 . Women have sought to gain membership in men's clubs where significant professional and business contacts often occur. See generally, Burns, The Exclusion of Women From Influential Men's Clubs: The Inner Sanctum and the Myth of Full Equality, 18 HAR C.R.-C.L.L.ReV. 321 (1983). Professor Rhode suggests a different viewpoint than Justice Brennan's. "An alternative theoretical framework for evaluating separatist associations should neither minimize the values at issue nor assume their primacy for all selective organizations. Such an approach requires a greater sensitivity to context, to the varying cultural functions, meanings, and consequences of particular social relationships. Rhode, Association and Assimilation, 81 Nw. U.L. Rev. 106, 124 (1986).

${ }^{101} 468$ U.S. at 629.

102 Speech by Justice Brennan at Georgetown University. The Constitution of the United States: Contemporary Ratification (Oct. 12, 1985), REPRINTED IN A. Mason and D. Stephenson, American Constitutional Law (1987). 
Framers' original intent. In fact, Brennan viewed the Framers' intent as essentially indiscemible, finding it "arrogant to pretend that from our vantage we can gauge accurately the intent of the Framers on application of principle to specific, contemporary questions." 103

Justice Brennan's dissenting opinion in Michael $H$. v. Gerald $D .^{104}$ evinces his view on individual privacy and autonomy. Michael $H$. sought to maintain a relationship with his biological daughter although the child's mother was married to another man. ${ }^{105}$ The controlling Califomia statute established a conclusive presumption in favor of the paternity of the mother's husband. ${ }^{106}$ Writing for a plurality, Justice Scalia concluded that the "liberty" protected by substantive due process extended only to the liberty to engage in activities which have been protected "traditionally" from societal or state control. ${ }^{107}$ Since Michael H.'s parental interest as an "adulterous biological father" had not been protected by societal or constitutional tradition, Scalia found the California conclusive presumption constitutionally valid. ${ }^{108}$

Justice Brennan, in dissent, found Scalia's interpretation so narrow as to destroy the doctrine of substantive due process. ${ }^{109}$ Admittedly, the legal "tradition" of the nation contains statutes criminalizing both abortion and the distribution of contraceptive devices. As a result, Brennan found Scalia's approach to be so limiting as to provide no real limit. ${ }^{110}$ Brennan argued that societal tradition is not the necessary condition to defining liberty which is protected from state action. Although recognizing the relevance of tradition, Brennan argued that the tradition which delineates the parameters of "liberty" is general, not specific. ${ }^{111}$ Therefore, the liberties protected by due process are embodied in the general tradition precedentially protected by the Supreme Court,

${ }^{103}$ Id.

${ }^{104} 109$ S. Ct. 2333 (1989).

${ }^{105}$ Id. at 2335.

${ }^{106}$ Id.

${ }^{107}$ Id. at 2346.

108 Id. at 2344.

${ }^{109}$ Id. at 2350-51 (Brennan, J., dissenting). Scalia's test would invalidate the following Supreme Court decisions: Cruzan v. Director, Mo. Dept't of Health, 110 S. Ct. 2841 (1990) (upholding right to die); Roe v. Wade, 410 U.S. 113 (1973) (upholding right to abortion); Eisenstadt v. Baird, 405 U.S. 438 (1972) (upholding right of unmarried individuals to use contraceptive devices); Griswold v. Connecticut, 381 U.S. 479 (1965) (upholding right of married individuals to use contraceptive devices). See also, Tribe, "Commentary-The Abortion Funding Conundrum: Inalienable Rights, Affirmative Duties, and the Dilemma of Dependence," 99 HARv. L.REv. 330 (1985) (arguing denial of abortion rights helps perpetuate hierarchical relationships in which women are subjugated).

${ }^{110}$ Michael H., at 2349 (Brennan, J., dissenting).

111 Id. at 2350. 
including parenthood, contraception and reproduction. ${ }^{112}$ Indeed, under Justice Brennan's view, the tradition protecting Michael H.'s liberty interest exists in the Supreme Court decisions which affirmed the right of unwed fathers to parent their children. ${ }^{113}$ In effect, the California conclusive presumption violated this Supreme Court tradition ${ }^{114}$

Justice Brennan's view conceming the personal right to choose abortion confirms his determination to protect individual autonomy and privacy as basic civil rights. In Harris v. McRae, ${ }^{115}$ Justice Brennan dissented from the Court's holding that the Hyde Amendment's denial of public funding for certain medically necessary abortions subject to medicaid funding does not contravene the equal protection or liberty guarantees of the Due Process Clauses. ${ }^{116}$ Brennan's dissent underscored his views that Roe v. Wade and its progeny guarantee the constitutional right to personal privacy, protecting women from governmental interference during the first trimester. ${ }^{117}$ Specifically, Brennan concluded that "the state must refrain from wielding its enormous power and influence in a manner that burden the pregnant woman's freedom to choose whether to have an abortion. ${ }^{118}$

Significantly, Justice Brennan is one of the first members of the Court to treat gender-related characteristics, such as pregnancy, in non-discriminatory terms. Justice Brennan's approach contributed in the most significant manner to the debate conceming the definition and desirability of equality between women and men. Justice Brennan rejected the concept that most sex-based differences are "real" and biologically determined. ${ }^{119}$ Since American society is largely

112 Id.

${ }^{113}$ Id. at 2351-55. See, e.g., Caban v. Mohammed, 441 U.S. 380 (1979); Stanley v. Illinois, 405 U.S. 645 (1972).

${ }^{114}$ Michael $H$., at 2355.

115448 U.S. 297 (1980) (Brennan, J., dissenting).

${ }^{116}$ Id. at 329.

117410 U.S. 113 (1973).

118448 U.S. at 329. See also, Justice Brennan's dissent in Planned Parenthood Ass'n of Kansas City, Mo., Inc. v. Ashcrofh, 462 U.S. 476, 499 (1983), arguing that the statutory second physician requirement is overbroad where matemal health considerations required the use of procedures, such as dilation and evacuation, which leave no possibility of fetal survival.

119 See e.g., Kirchberg v. Feenstra, 450 U.S. 455, 463 (1981) (Rehnquist, J., joining Stewart, J., concurring in the result); Dothard v. Rawlinson, 433 U.S. 321, 337 (1977) (Rehnquist, J., concurring in pertinent part). The "real" sex differences approach stresses gender distinctions which are "real" in the sense of being "natural" or "biological", such as pregnancy, menstruation or lactation. The significant question to the "real" differences proponents is whether women and men are different in fact with respect to a specific legislative classification. See also, Michael M. v. Superior Court, 450 U.S. 464 (1981) (plurality opinion) (pregnancy as a "natural" deterrent to sexual intercourse for young women, but not young men). Classifications based on such "real" differences are often over-inclusive in that many members of each gender lack the reproductive characteristics defining their sex. For example, excluding all women from a particular workplace because of dangers to reproduction would be over-inclusive to the extent that some 
characterized by sex differentiation, gender segregation, and gender-based hierarchical structures in the home, in the workplace and in the legislature, even facially neutral laws are likely to have a disparate impact on either men or women. ${ }^{120}$ For example, seemingly neutral rules such as seniority and tenure, in fact discriminate against women because mothers, rather than fathers, are likely to intermut their working lives to parent. ${ }^{121}$

\section{Privacy, "Real" Gender Differences and Pregnancy}

Although explicit gender classifications involving pregnancy have been deemed constitutionally valid because only women can become pregnant, ${ }^{122}$ the Court has exhibited substantial difficulty in dealing with pregnancy legislation. The fact that pregnancy is gender specific has raised doctrinal problems and inconsistencies in the decisional law. Indeed, the Court has exhibited considerable reluctance to treat pregnancy classifications as sex-based discrimination. Significantly, the Court has had considerable difficulty in even perceiving disparate treatment issues in pregnancy classifications.

In Cleveland Bd. of Education v. LaFleur, ${ }^{123}$ the Court considered two mandatory matemity leave policies which excluded pregnant teachers from the classroom even though the teachers were willing and able to teach. ${ }^{124}$ The circuit courts of appeals had treated the problem as one of equal protection. ${ }^{125}$ Nevertheless, the Supreme Court chose to strike down the policies on due process grounds: the policies constituted impermissible irrebuttable presumptions about the pregnant woman's capacity to work, unduly burdening her fundamental right to bear a child. ${ }^{126}$

As previously discussed, the Court did apply equal protection analysis to

women are infertile.

${ }^{120}$ See, e.g., Goode, Why Men Resist in Rethinking the Family 131 (B. Thome \& M. Yalour eds. 1982); Note, Toward a Redefinition of Sexual Equality, 95 HARV. L. REV. 487 (1981).

${ }^{121}$ See, e.8., Beck, The Gender Factory (1985); Liefland, Career Patterns of Male and Female Lowyers, 35 BUFF. L. REv. 601 (1986) (women lawyers act as primary childcare providers within the family); Weiler, The Wages of Sex: The Uses and Limits of Comparable Worth, 99 HARV. L. REV. 1728, 1785-87 (1986).

${ }^{12}$ See Michael M., 450 U.S. 464 (1981).

12414 U.S. 632 (1974). Justice Stewart wrote the majority opinion joined by Justices Brennan, White, Marshall and Blackmun. Justices Douglas and Powell concurred, while Chief Justice Burger and Justice Rehnquist dissented.

124 Id. at 645.

18 LaFleur v. Cleveland Bd. of Education, 465 F.2d 1184 (6th Cir. 1972) (classification based on sex). cf. Cohen v. Chesterfield County School Bd., 474 F.2d 395, 397 (4th Cir. 1973) (no sex discrimination present because pregnancy rules do "not apply to women in an area in which they compete with men.").

${ }^{126} 414$ U.S. at $644-48$. 
pregnancy in Geduldig $v$. Aiello. ${ }^{127}$ The Califomia disability insurance scheme covered numerous conditions, some expensive or voluntary, which applied to both sexes. The scheme also covered some health conditions unique to men, such as circumcision and prostatitis, while excluding normal pregnancy and childbirth. ${ }^{28}$ The majority applied the minimum rationality standard, holding that the equal protection clause did not mandate the "sacrifice" of California's disability system. ${ }^{129}$

Justice Brennan dissented. ${ }^{130}$ Unlike the majority, Brennan recognized that pregnancy-related disabilities are truly gender-linked disabilities since they result from physical characteristics inextricably possessed by women. ${ }^{131}$ Justice Brennan accurately concluded that treating pregnancy disabilities differently than male sex-linked disabilities such as prostatitis constituted sex discrimination. ${ }^{132}$

The Court continued its incredible and unworkable approach to pregnancy in the Title VII case, General Electric v. Gilbert. ${ }^{133}$ Despite the Equal Employment Opportunity Commission's promulgation of guidelines construing Title VII of the Civil Rights Act $^{134}$ to mandate pregnancy coverage, ${ }^{135}$ the Court denied relief to women whose company disability policy extended benefits for nonoccupational health problems, while excluding pregnancy. ${ }^{136}$ Again, the majority distinguished between pregnant and unpregnant persons, stressing the fact that pregnancy is "often a voluntarily undertaken and desired condition."

\footnotetext{
${ }^{127}$ See supra note 86 and accompanying text. The Geduldig majority dismissed the gender discrimination issue in a footnote, 417 U.S. at 496-97. ("lack of identity between the excluded disability and gender as such under this insurance program becomes clear upon the most cursory analysis. The California insurance program does not exclude anyone from benefit eligibility because of gender but merely removes one physical condition pregnancy-from the list of compensable disabilities. ... The program divides potential recipients into two groups pregnant women and nonpregnant persons. While the first group is exclusively female, the second includes members of both sexes").

${ }^{123}$ Geduldig at 501.

${ }^{129}$ Id. at 494.

${ }^{130}$ Id. at 498 (Brennan, J., dissenting).

${ }^{131}$ Id. at 501.

${ }^{132}$ Id. at 501.

${ }^{133} 429$ U.S. 125 (1976).

13442 U.S.C. $\$ 2000 \mathrm{e}-2(\mathrm{a})(1)$.

135 The Court found the statute's "plain meaning" did not mandate pregnancy coverage. 429 U.S. 125, 145; $c f$. Chevron U.S.A. Inc. v. NRDC, Inc., 467 U.S. 837, $860-65$ (1984).

${ }^{136}$ Id. at 145.

${ }^{137}$ Id. However, vasectomy, which is also "voluntary" was covered by the General Electric plan. See Bartlett, Pregnancy and the Constitution: The Uniqueness Trap, 62 CAL. L. REV. 1532, 1561-63 (1974). Eventually, Congress enacted the Pregnancy Discrimination Act ("PDA") of 1978, amending Title VII to include pregnancy classifications within the definition of sex discrimination. See also, Newport News Shipbuilding \& Dry Dock Co. v. E.E.O.C., 462 U.S. 669, 684 (1983) ("discrimination based on a woman's pregnancy is, on its face, discrimination because of her sex").
} 
Naturally, Justice Brennan dissented. ${ }^{138}$ Brennan rejected the majority's insistence that pregnancy is a "gender-free" classification. ${ }^{139}$ Significantly, Brennan argued that the majority's analysis "proves to be simplistic and misleading". ${ }^{140}$ Emphasizing the fact that all other sex-specific disabilities were covered by the plan, Justice Brennan concluded that excluding pregnancy disadvantaged women in the workplace. ${ }^{141}$ The General Electric plan, therefore, discriminated against women by encouraging outmoded stereotypes of women in the workplace. ${ }^{142}$

As such, Justice Brennan recognized that historical and societal attitudes towards women and pregnancy, rather than "real" gender differences created legal disabilities for women. ${ }^{143}$ Brennan's analysis promotes gender equality by recognizing that the injury of sex discrimination rests in being deprived of political, legal, or educational opportunity merely because one is a woman or a man. ${ }^{144}$ The genius of Justice Brennan's gender jurisprudence as it related to pregnancy is that he demanded the law abandon negative stereotypes in favor of equal treatment for women and men.

\section{"Benign" Gender Discrimination}

Justice Brennan generally opposed sex-based classifications which had the "benign" purpose of "compensat[ing] female beneficiaries as a group for the economic difficulties which still confront women who seek to support themselves and their families." 145 As previously discussed, Justice Brennan routinely

\footnotetext{
138 Gilbert, 429 U.S. at 146.

139 Id. at 147.

140 Id. at 152.

141 Id at 155.

102 Id. at $159-60$.

${ }^{143}$ Id.
}

144 Feminist writers disagree fundamentally on the question of whether pregnancy requires "special" treatment. Minimizing the legal consequences of physical differences between women and men has been an accepted methodology under equal protection analysis. This "equal treatment" or "assimilationist" model treats man as the standard by which equality is defined. However, this approach may prove unworkable as applied to pregnancy classifications. See generally, Kay, Models of Equality, 1985 U. ILL. L. REV. 39 (1985); Law, Rethinking Sex and the Constitution, 132 U. PA. L. REV. 955 (1984). Treating women and men as similarly situated on issues of pregnancy and reproduction may, in fact, violate equal protection considerations in that women and men are not the same for reproductive purpose. Simply stated, "pregnancy ... and creation of another human being are special .- very special. Women have these experiences. Men do not." Law, supra at 1007. See also Williams, Equality's Riddle: Pregnancy and Equal Treatment/Special Trealment Debate, 13 N.Y. U. REV. L. \& SoC. CHANGE 325 (1984); MacKinnon, Introduction to Symposium on Sexual Harassment, 10 CAP. U. L. REV. I, VI. n.21 (1981).

145 Weinberger v. Wiesenfeld, 420 U.S. 636, 648 (1978) (rejecting this "benign" purpose as illegal discrimination). cf. Johnson v. Santa Clara Transportation Agency, 107 S. Ct. 1442 (1987), where Justice Brennan, writing for the Court, upheld a voluntarily-adopted affirmative action plan under Title VII which permitted gender to be considered as one factor in jobs, such as dispatcher, in which women are underrepresented significantly. Professor Sullivan argues that voluntary affirmative action programs should not 
rejected remedial measures grounded in the "romantic paternalism"146 which actually perpetuates traditional sex roles. Brennan feared that even those genderbased classifications which govemment considered "an affirmative step toward alleviating the effects of past economic discrimination against women"147 ultimately promoted the very gender stereotypes which foster gender inequality. ${ }^{148}$

As previously discussed, Kahn v. Shevin, ${ }^{149}$ is an example of "benign" or remedial legislation endorsed by the Court, but condemned by Justice Brennan. ${ }^{150}$ In Kahn, Justice Douglas, writing for the majority, upheld an 1885 Florida statute granting all widows a limited property tax exemption. ${ }^{151}$ Although the 1855 enactment date belies the legislative intent of "alleviating the effects of past economic discrimination against women", Justice Douglas explicitly adopted Florida's rationale. Justice Douglas reasoned that "[w]hether from overt discrimination or from the socialization process of a male-dominated culture, the job market is inhospitable to the women seeking any but the lowest paid jobs." ${ }^{152}$ Citing data demonstrating that the median income of working women was less than sixty percent of the male median, Justice Douglas concluded that:

The disparity is likely to be exacerbated for the widow. While the widower can usually continue in the occupation which preceded his spouse's death, in many cases the widow will find herself suddenly forced into a job market with which she is unfamiliar, and in which, because of her former economic dependency, she will have fewer skills to offer. ${ }^{153}$

require the same degree of judicial suspicion as court - ordered remedies. Sullivan, The Supreme Court, 1986 Term -- Comment: Sins of Discrimination: Last Term's Affirmative Action Cases, 100 HARV. L. REv. 78, 96-97 (1986). cf. Days, Fullilove. 96 YALE L.J. 451, 483-84 (1987), arguing that voluntary affirmative action programs must be justified by more extensive demonstrations of past discrimination because "more than good motives should be required when government seeks to allocate its resources by way of an explicit racial classification system. It must be shown that such a system is responsive to findings of racial discrimination, is designed to redress that problem, and is employed only as long as is necessary to achieve its remedial objective." Id.

${ }^{146}$ Califano v. Webster, 430 U.S. 313, 320 (1977) (per curiam).

${ }^{147}$ Kahn v. Shevin, 416 U.S. 351,358 (1974) (Brennan, J., dissenting).

${ }^{148}$ See also Justice Stevens' dissenting opinion in Mathews v. Lucas, 427 U.S. 495, $520-21$ (1976): "Habit, rather than analysis, makes it seem acceptable and natural to distinguish between male and female.... But that sort of stereotyped reaction may have no rational relationship - other than pure prejudicial discrimination - to the stated purpose for which the classification is being made." $J d$.

${ }^{149} 416$ U.S. 351 (1974).

$150 \mathrm{Jd}$. at 358.

${ }^{151}$ Id. at 355.

152 Id. at 353.

${ }^{153}$ Id. at 354. 
Although Justice Douglas' sensitivity to the pervasiveness of economic discrimination against women is commendable, it fails to justify the establishment of a permanent, separate legal classification for all widows, regardless of their actual wealth, business experience, or gender victimization. Indeed, the legislative classification in Kahn promotes the outmoded stereotypes of women which create and perpetuate workplace inequality. Essentially, Justice Douglas undermines his own sensitivity to gender discrimination by justifying the continued use of discriminatory sex-based classifications to remedy past inequities.

Justice Brennan understood this paradox. He insisted that legislative classifications (such as the one in Kahn) adversely affecting men should be subjected to the same scrutiny as sex-based laws discriminating against women. Significantly, Justice Brennan opposed most sex-based classifications as endorsing sex discrimination which is both constitutionally and morally problematic. Although Justice Brennan acknowledged the nation's "long and unfortunate history of sex discrimination, ${ }^{154}$ his gender jurisprudence explicitly rejected "benign" laws which burdened men in the name of remedying discrimination against women. Implicitly, Justice Brennan recognized that such "benign" legislative schemes actually embrace the outmoded stereotypes which relegate women to a different, unequal sphere. Ultimately, such remedial or benign classifications place women, not on a pedestal, but in a cage.

As a result, Brennan's gender jurisprudence contributes significantly to the essential debate conceming the meaning of gender equality. Rejecting the unreflective biologic determinism permeating most sex-based classifications, Brennan sought to replace them with gender-neutral alternatives. Accordingly, Justice Brennan drafted the plurality opinion in Califano v. Goldfarb. ${ }^{155}$ There, the Court invalidated a Social Security provision providing survivor benefits to widowers only on a showing of substantial reliance on the deceased wife's income, while paying benefits to all widows, regardless of economic dependence. $^{156}$ The dissenters, led by Justice Rehnquist, were troubled by the fact that male litigants were able to invalidate legislation on the basis of sex-based discrimination without demonstrating that men are historically, economically, or politically disadvantaged. ${ }^{157}$ Indeed, most of the benign discrimination cases brought to date have been instituted by males seeking "advantaged" treatment as

\footnotetext{
154411 U.S. $677,687$.

1ss 430 U.S. 199 (1977).

136 Id. at 217.

157 Craig, 429 U.S. at 218-19 (Rehnquist, J., dissenting). Justice Rehnquist has argued consistently that men are not historical victims of economic or political discrimination. Therefore, men, unlike women, are not "in need of the special solicitude of the courts." Michael M., 450 U.S. 464 (1981).
} 
women. ${ }^{158}$ These men did not want preferential treatment to be terminated-rather, they wanted the preferential treatment extended to themselves. In this respect there is no analog between "benign" or remedial racial legislation and remedial gender legislation. In racial discrimination legislation, the minority group seeks only one goal: attainment of the status accorded for white males. On the other hand, gender discrimination litigation follows two themes: ${ }^{159}$ women seek to be treated like men in the workplace ${ }^{160}$ and men seek to be treated like women in the area of personal or family life. ${ }^{161}$

\section{CONCLUSION}

It is virtually impossible to overestimate Justice Brennan's impact on the Supreme Court's gender jurisprudence. Although Brennan was unable to forge a majority to treat sex as a suspect classification, his attempts to create such an analytical framework helped the Court emerge from decades of paternalism and discrimination.

Justice Brennan once stated:

[T] mean in our time. For the genius of the Constitution rests not in any static meaning it might have had in a world that is dead and gone, but in adaptability of its great principles to cope with current problems and current needs. ${ }^{162}$

Justice Brennan deserves great credit for crafting a unique, far-reaching gender jurisprudence. His greatness is not only that he was creative and courageous, but that he urged both the Court and society to be creative and courageous, as well. To all familiar with his gender jurisprudence, Justice Brennan shall be remembered as one of the most innovative protectors of equal treatment before the law.

\footnotetext{
${ }^{158}$ See, e.g., Weinberger v. Wisenfeld, 420 U.S. 636 (1975) (male seeking "mother's benefits" as surviving parent); Orr v. Orr, 440 U.S. 268 (1979) (male seeking overturn of State law permitting alimony awards only to women); Wengler v. Druggists Mulual Ins. Co., 446 U.S. 142 (1980) (male seeking worker compensation benefits provided only to widows).

159 Kay, Models of Equality, 1985 UNIV. ILL. L. ReV. 39, 45-47, 75-77 (1985).

${ }^{160}$ See, e.g., Roberts v. United States Jaycees, 468 U.S. 609 (1984); Turner v. Department of Employment Security, 423 U.S. 44 (1975).

161 See, e.g., Caban v. Mohammad, 441 U.S. 380 (1979); Stanley v. Illinois, 405 U.S. 645 (1972).

162 See Brennan, supra, note 102, at 610 .
} 